\title{
Problems of small countries in linking research to industry
}

Ottawa

SMALl countries may have special problems in finding a way to link basic research to the industrial research and development needed for economic prosperity, according to a new report* .

The thrust of basic research in small countries will "be primarily determined by the links that scientists form with their peers in the international basic research community". In contrast, in those with a strong industrial science base, some basic research will be naturally linked to the industrial innovation process.

At one pole are countries such as Canada and Australia whose industries carry out very little research and exert almost no influence on basic research. They, and countries such as Britain which have the same historical tradition, share the problem of being unable to link science (based in universities) effectively to technology (based in industry). But the problems are worse for the smaller countries where it is very difficult to start technological growth in industry.

At the other pole stands Japan which has "come to science from engineering and technology". Basic research laboratories are being built up in industry, rather than in the universities, and so can directly enhance effective applied research.

The report argues that innovation cannot be produced by putting pressure on the universities "to act as surrogates for what industry should be doing". Small countries have to come up with new institutional arrangements to "pool resources within and outside their country" and learn how to maintain the integrity of the pyramid of basic, applied and developmental research within industry.

They face stiff competition. The combined research and development budget of Japan's six big electronics companies is almost as big as the entire research and development budget of Italy and bigger than those of any Western nation excluding the United States, Germany, France and Britain.

Small countries can, however, do well, as Sweden and Switzerland show. Canada is given a fair chance of improving its miserable position at the bottom of almost every measure of research and development performance in the OECD league table. The economy is expected to do well for the next five years and will provide a stable period for change. The new principles needed include trust and consensus among all the different political, industrial and research actors and an agreement that major priorities for science-based innovation must be industry-driven

Alun Anderson

* Innovation and Canada's Prosperity: The transforming power of science, engineering and rechnology (Canadian Institute for Advanced Research, 179 John Streeet, Suite 701 Ontario M5T 1X4. Canada)

\section{Aflatoxin contamination of US corn}

\section{Washington}

THE severe drought in US corn-producing states last summer not only reduced this year's corn crop but also gave a foothold to crop contamination by a mould which produces the most carcinogenic natural product known: aflatoxin. An Iowa State University survey released last week of aflatoxin contamination of corn in Iowa grain elevators revealed that over one-third has levels of aflatoxin toxic to humans. Illinois and Indiana have reported similar levels, and aflatoxin has also been detected in corn grown in Wisconsin and Minnesota.

Aflatoxin is produced by roughly half of the natural population of Aspergillus flavus, a ubiquitous mould which invades only corn that has been stressed by high temperatures and low moisture. Aflatoxin contamination is relatively common in southern states such as Georgia and Alabama, but troubling levels have not been found in midwestern corn crops since 1983.

The US Food and Drug Administration (FDA) outlawed the interstate shipping and foreign export of corn containing aflatoxin levels greater than 20 parts per billion $\left(10^{9}\right)$, the highest amount reckoned safe for

human consumption. But beef cattle are able to metabolize larger amounts of aflatoxin without tainting the meat, so the FDA raised the maximum levels allowed in feed earlier this month. Under the new rules, mature cattle can eat corn containing up to 300 parts per billion aflatoxin, swine can consume feed with 200 , and breeding livestock are allowed 100. Because dairy cattle can pass the toxin along in their milk, corn fed to dairy cattle must contain no more than 20 parts per billion aflatoxin.

But critics of the new FDA regulations say that dividing up the corn crop by aflatoxin level is not a workable solution. Local grain elevators routinely screen corn delivered by farmers by passing it under an ultraviolet light to detect mould, but the elevators are not capable of assaying corn specifically for aflatoxin. Most grain is tested for aflatoxin just before it is bought and shipped, and large buyers of corn may be reluctant to purchase shipments which have restricted uses. Charles Hurburgh, who headed the Iowa survey, says "the scrutiny is tightening by the day" and that market pressures will keep higher-aflatoxin corn from being sold.
Delhi science centre New Delhi

A SCIENCE and technology centre for nonaligned countries is to be opened in New Delhi early in 1989. The centre has been under discussion for two years.

Thirty-one non-aligned developing nations, including China and Pakistan, have agreed to participate. Others are expected to join before the governing council meeting in February 1989 that will settle remaining issues of funding and organization.

A spokesman of the Indian Department of Science and Technology said one aim of the centre is to pool the talent and resources available within the non-aligned nations to promote collective self-reliance and reduce dependence on the West.

A recent meeting of scientists from 25 countries identified five areas for joint ventures in research and development: information and telecommunications, microelectronics, computer software, biotechnology and renewable sources of energy. The centre proposes to set up common databanks and information networks covering these fields. There are also proposals for computer time-sharing and exchange of scientists and students.

The centre will also try to develop collective strategies to deal with such issues as the dumping of toxic wastes by industrialized nations, and the impact of advanced technologies on the economies of developing countries.

K. S. Jayaraman

\section{South Africa avoids expulsion again}

\section{Oxford}

South Africa successfully staved off expulsion from the International Atomic Energy Agency (IAEA) yet again at the organization's annual general assembly in Vienna last month. A group of African countries, led by Nigeria, were forced to back down from a bid to oust South Africa from the agency, after the Soviet Union and other Eastern bloc states failed to support the move for the second year running.

The group said that it had been forced to withdraw its resolution until next year's conference, after Soviet delegates had indicated that they believed South Africa would soon sign the Nuclear Non-Proliferation Treaty (NPT). In August, a South African delegation was urged by British, US and Soviet representatives to do so, and in September a second delegation met the representatives of 30 countries to get clarification on the terms of the treaty.

A spokesman for the South African Department of Foreign Affairs said that an in-depth study of the implications of signing the treaty had been accorded priority status. Until this was completed, he claimed, the country would not commit itself to signing the NPT. Michael Cherry 